\title{
Hydrogeochemical Processes Governing Uranium Mobility: Inferences from the Anthropogenically Disturbed, Semi-arid Region of India
}

anita punia ( $\sim$ puniaanita12@gmail.com )

Indian Institute of Technology Guwahati https://orcid.org/0000-0002-2572-7463

Rishikesh Bharti

Indian Institute of Technology Guwahati

Pankaj Kumar

Inter-University Accelerator Centre

\section{Research Article}

Keywords: Heavy metals, Geochemical process, Uranium mobilisation, Khetri Copper Belt

Posted Date: April 30th, 2021

DOl: https://doi.org/10.21203/rs.3.rs-466586/v1

License: (1) This work is licensed under a Creative Commons Attribution 4.0 International License.

Read Full License

Version of Record: A version of this preprint was published at Archives of Environmental Contamination and Toxicology on August 4th, 2021. See the published version at https://doi.org/10.1007/s00244-02100879-3. 


\section{Hydrogeochemical processes governing Uranium mobility: Inferences from}

2 the anthropogenically disturbed, semi-arid region of India

3 Anita Punia ${ }^{a^{*}}$, Rishikesh Bharti ${ }^{\text {** }}$ and Pankaj Kumar ${ }^{\mathrm{b}}$

$4 \quad{ }^{a}$ Department of Civil Engineering, Indian Institute of Technology, Guwahati, India

5 bInter-University Accelerator Centre (IUAC), New Delhi

6 Corresponding author email: puniaanita12@iitg.ac.in; rbharti@iitg.ac.in

\section{Abstract}

Khetri Copper Belt, Rajasthan is anthropogenically active and geologically belongs to the Delhi supergroup. To study the active geochemical processes controlling the elemental mobility, representative groundwater samples were analysed for heavy metals and radionuclide (U). A maximum $\mathrm{U}$ concentration (average $87 \mu \mathrm{gL}^{-1}$ ) is observed in the quartzite mine zone whereas minimum (average $13 \mu \mathrm{gL}^{-1}$ ) is found to be in the copper mine zone samples. Despite the presence of Jaspura and Gothra granitoid in the copper mine zone, the abundance of $U$ is low suggesting the scavenging of $U$ by sulphides or iron oxides. Additionally, at the confluence of two geological groups, Fe concentration is found high with a low concentration of $U$ which further confirms scavenging of $U$. In the region, aquifers are shallow which supports the weathering of minerals. Thus, a high concentration of $U$ in groundwater is attributed to mineral dissolution, faults or fractures. It is evident from the results that in the absence of iron-bearing sulphides, $\mathrm{U}$ concentration in groundwater would be very high compared to the current concentration. It also indicates low concentration of $U$ in the copper mine zone, area is covered with abundant quantity of Fe sulphide rich waste. The present study recommends further research to understand the feasibility of mining waste for the removal of $\mathrm{U}$ contamination from groundwater.

Keywords Heavy metals; Geochemical process; Uranium mobilisation; Khetri Copper Belt

\section{Introduction}

Uranium (U) is a carcinogenic radionuclide and excessive consumption poses a potential health risk to humans (Blantz et al. 1985). $\mathrm{U}$ accumulates in organs and tissues of the human body and causes various health hazards (Russell and Kathren 2004; Wei et al. 2019). It leads to chronic disorders of the liver, kidney and bones (Craft et al. 2004; Brugge and Buchner 2011; Katz 2014). The most important route of U entry is through drinking water. World Health Organisation (WHO) recommends $30 \mu \mathrm{g} \mathrm{L}^{-1}$ as a permissible limit for drinking water (WHO 2011) exceeding this permissible limit could cause chronic health impacts on human beings.

Sources of ions in groundwater are being controlled by both anthropogenic and geogenic processes. Anthropogenically, contamination of groundwater due to $\mathrm{U}$ mines is reported in different countries such as Poland (Kozak et al. 2013), France (Cuvier et al. 2015), Portugal (Neiva et al. 2014), Spain (Villa et al. 2011) and Serbia (Momčilović et al. 2013). A high concentration of $\mathrm{U}$ in groundwater is attributed to the abundance of U-rich 
mining waste. Simultaneously, some studies suggested geogenic origin of $U$ in groundwater worldwide namely Korea (Shin et al. 2016), USA (Burow et al. 2017), Switzerland (Stalder et al. 2012), Germany (Liesch et al. 2015) and China (Wu et al. 2014).

In India high concentration of $U$ is found in the states of Punjab (Sharma et al., 2019), Himachal Pradesh (Rani et al. 2013), Jharkhand (Patra et al. 2013), Tamil Naidu (Selvi et al. 2016) and Jammu and Kashmir (Sharma et al. 2017). A high concentration of $U$ is observed in different parts of Rajasthan specially in Sikar (Duggal et al. 2016), Jaipur, Ajmer, Tonk, Kota, Jodhpur, and Barmer (Coyte et al. 2019). Hence it is important to understand the geochemical processes governing $\mathrm{U}$ mobility in natural conditions.

The high content of uranium is found in the forms of carbonates (Andersonite, Bayleyite and Grimselite), phosphates (Autunite and Torbernite), oxides (Metaschoepite, Metastudtite and Uraninite) and silicates (Uraninite and Swamboite) (Deditius et al. 2008; Gorman-Lewis et al. 2007; Gorman-Lewis et al. 2008a \& b; O'Brien and Williams 1983; Ray et al. 2011; Locock and Burns 2003; Gorman-Lewis et al. 2009). Groundwater depletion leads to the dissolution of minerals and enhances elemental mobility. Uraninite is insoluble and is readily oxidized through rock-water interactions to soluble uranyl ions $\left(\mathrm{U}(\mathrm{VI}) \mathrm{O}_{2}{ }^{2+}\right)$ through dissolution, complex formation and desorption-sorption (Tricca et al. 2000). Under anoxic conditions reduced sulfur and iron species may reduce $\mathrm{U}(\mathrm{VI})$ to $\mathrm{U}_{3} \mathrm{O}_{8} / \mathrm{U}_{4} \mathrm{O}_{9} / \mathrm{UO}_{2}$ (Hua and Deng, 2008) (Eq. 1-4).

$\mathrm{UO}_{2}^{2+}+\equiv \mathrm{FeS} \leftrightarrow \equiv \mathrm{S}^{2-}-\mathrm{UO}_{2}^{2+}+\mathrm{Fe}^{2+}$

$\equiv S^{2-}-U O_{2}^{2+} \leftrightarrow S^{0}(s)-U O_{2}(s)$

$\mathrm{FeS}(\mathrm{s})+\mathrm{H}_{2} \mathrm{O} \leftrightarrow \mathrm{Fe}^{2+}+\mathrm{HS}^{-}+\mathrm{OH}^{-}$

$U O_{2}^{2+}+H S^{-} \leftrightarrow U O_{2}(s)-S^{0}(s)+H^{+}$

Natural factors such as geology and geochemical processes such as ion exchange, precipitation, complexation or redox reaction play an important role in releasing the $\mathrm{U}$ from minerals to groundwater. Migration of $\mathrm{U}$ through sulphide, silicate and carbonate-rich geological setup influence the chemical composition of groundwater. In the mining region dissolution of sulphides contaminates groundwater with a high concentration of heavy metals (Tomiyama et al. 2019; Cánovas et al. 2016). Sulphides specifically Fe, affects the mobility of U by adsorbing on its surface through substitution (Cumberland et al. 2016) or ion exchange process (Jang et al. 2008). In contrast, Paradis et al. (2016) suggested reduced sulfur-bearing species are not fully effective to limit the mobility of U. In the carbonate-rich region, adsorption of $\mathrm{U}$ on soil decreases significantly because of the formation of negativelycharged uranyl carbonate (Giblin et al. 1981).

Geological features such as fractures and faults also create oxidising conditions. Under oxic conditions dissolution of Fe-rich minerals increases and thus in groundwater (Smith and Roychoudhury 2013). Groundwater present in the fracture zone is prone to more contamination. Fracture zones yield most of the water and are also helpful in locating the available water resources (Banks et al., 1992). The iron-bearing minerals adsorb and immobilize the $\mathrm{U}(\mathrm{VI})$-bearing species at circumneutral $\mathrm{pH}$ under oxidizing conditions ( $\mathrm{Li}$ and Kaplan 2012). U gets mobilise in the presence of oxygen and nitrate in groundwater (Watson et al. 2013).

Due to the complex behaviour of $\mathrm{U}$, geochemical processes governing the $\mathrm{U}$ mobility in groundwater are difficult to understand. Considering this the region active for mining for different types of minerals such as granite, 
quartzite, and copper is selected. The selected study area would be helpful in better understanding the perspectives of $\mathrm{U}$ mobility under the influence of different types of anthropogenic and geogenic factors. The main aim is to understand (1) the impact of mining on the concentration of $\mathrm{Fe}, \mathrm{Mn}$ and $\mathrm{U}$ and (2) understanding the perspectives of $\mathrm{U}$ mobility under the influence of different types of anthropogenic and geogenic factors.

\section{Study Area}

The study area is well known for copper mines and it is located in the Jhunjhunu district of the Indian state Rajasthan (Fig. 1a). It is located at an altitude of approximately $370 \mathrm{~m}$ above mean sea level with $\mathrm{N} 28^{\circ} 04.070^{\prime}$ latitudes and E $75^{\circ} 49.294^{\prime}$ longitudes. The region is famous as a Khetri Copper Belt (KBC) since historical times and it extends from Singhana (north) to Raghunathgarh (South) which is $\sim 0 \mathrm{~km}$ in length. Rocks of Khetri complex are comprises of metasedimentary and igneous intruded by granitoids (Sarkar and Dasgupta 1980; Gupta et al. 1998).

Geologically, the study area falls in the Delhi supergroup and is divided into northern (North Delhi fold belt) and southern (South Delhi fold belt) parts by Kantli fault (NW-SE transverse) (Gupta et al. 1998). Rocks of the supergroup undergoes many folding and polyphase metamorphism (Kaur et al. 2012). The Delhi Supergroup rocks are divided into two groups based on age i.e. an older Alwar (dominate in psammite) and a younger Ajabgarh group (dominate in pelites) (Heron 1923; Das Gupta 1968). Most of the region is covered by the Ajabgarh group which is formed of metamorphosed argillites and calcareous followed by the Alwar group which dominantly consists of arenaceous. The Ajabgarh group is composed of schists and phyllites and intruded by basic rocks such as granites and amphibolites. The Alwar group is made up of various types of rocks and the composition varies from pure ortho-quartzites to arkose with bands of magnetite, hematite and amphibole. At the confluence of different lithological units (Ajabgarh and Alwar) major faults and fractures are observed (Roy Chowdhury and Das Gupta 1965). The juncture of Alwar and Ajabgarh is also enriched in iron oxide-copper-gold deposits (Knight et al. 2002). The metasomatic alternation of granites in the region are enriched in $U$ and rare earth elements mineralization (Kaur et al. 2014).

\section{Methodology}

\section{Sampling}

The groundwater samples were collected in May 2019 following the sampling protocols. The region is famous for copper (Khetri Nagar) mines but quartzite (Ishakpura) and granites (Papurana) mines are also active in the area. The sampling locations were categorized into 3 zones i.e. copper mine zone (CMZ), quartzite mine zone (QMZ) and granite mine zone (GMZ) depending on the type of mine. A total of 32 groundwater samples i.e. 7, 13 and 12 were collected from QMZ, CMZ and GMZ respectively. Considering each mine as a centre point, the sampling locations were distributed systematically in North, East, South and West directions. From each direction, a total of approximately 3 samples were collected after the interval of 2-3 km. The main constraint of sampling was the non-availability of functional hand-pumps. To avoid contamination due to the pipeline the groundwater pumped during the initial first 5 minutes was discarded. 

$\mathrm{HNO}_{3}$ (Radojevic and Bashkin 1999). After the addition of $\mathrm{HNO}_{3}$, the samples were filtered using standard pore size $0.45 \mu \mathrm{m}$ syringe filters at the sampling site. Before the sampling, the sample bottles were washed with Milli-

$112 \mathrm{Q}$ ultrapure and the sample itself to avoid contamination. Parameters such as $\mathrm{pH}, \mathrm{EC}$ and temperature of the samples were measured in-situ using a portable pH meter (Hanna instrument, H196107).

\section{Elemental and statistical Analysis}

The groundwater analysis for $\mathrm{Fe}, \mathrm{Mn}$ and radionuclide $\left({ }^{238} \mathrm{U}\right)$ was done using Inductively coupled plasma mass spectrometry (ICP-MS) at Inter-University Accelerator Centre (IUAC), New Delhi. The ICP-MS was calibrated using standard solutions of 1, 20, 50 and $100 \mu \mathrm{g} / \mathrm{L}$ prepared from $1000 \mu \mathrm{gL}^{-1}$ multi-element stock solution (1000 $\mu \mathrm{gL}^{-1}$ ) via dilution process. For QA/QC, standards namely DGH, MBH, JB-1a and AMH were used (Rathi et Al. 1994; Imai et Al. 1995; Saini et Al. 2013). To assess the precision and accuracy during the analysis elemental concentration in the blank (Milli Q prepared from $18.2 \mathrm{M} \Omega \cdot \mathrm{cm}$ Ultrapure, Sigma Aldrich) and standards were measured after every 10 samples. The elemental detection limit varies from $0.1-1000 \mu \mathrm{g} / \mathrm{L}$ for $\mathrm{Fe}, \mathrm{Mn}$ and radionuclide.

The statistical parameters such as average, standard deviation, and median were calculated for the interpretation of data. ArcGIS 10.6.1 was used for locating the sampling locations on the geological map using GPS locations. The inverse distance weighting (IDW) method was used for the multivariate interpolation of $U$ concentration. Graphs were plotted using the Grapher software (version 10).

\section{Risk assessment}

Drinking water containing excessive $\mathrm{U}$ for a longer duration adversely affects kidneys and bones (Zamora et al. 1998; Kurttio et al. 2005). The risk caused by excessive intake of U is calculated in terms of Average Daily Dose (ADD) via equation 5 (WHO 2011):

The full form of used abbreviation are as follows $\mathrm{U}=$ uranium concentration $(\mathrm{mg} / \mathrm{L})$, DWI= Daily Intake of Water (4.05 L per day) (Saini et al. 2016), EF = Exposure Frequency (350 days per year) (USEPA 1999), ED = Exposure Duration (65 years) $(\mathrm{WHO}, 2011), \mathrm{LE}=$ Life Expectancy (65 years with 365 days per year i.e. 23,725 days) and BW = Body Weight (53 kg of an adult Indian standard person) (Sharma et al. 2017). of contaminated water. HQ values less than 1 suggest no adverse health effects due to the consumption of uranium contaminated water (AERB 2004) and it was calculated using equation 6.

$\mathrm{HQ}=\frac{\mathrm{ADD}}{\mathrm{RD}}$

where RD indicates the Reference Dose.

\section{Results and discussions}


$143 \mathrm{U}$ concentration varies from 0.03 to $430 \mu \mathrm{gL}^{-1}$ with an average of $37 \mu \mathrm{gL}^{-1}$ indicating high contamination in the 144 region. U concentration exceeds or near the WHO permissible limit $\left(30 \mu \mathrm{gL}^{-1}\right)$ at most of locations. It is observed 145 high at all the sites falling in quartzites mine zone with an average concentration of $87 \mu \mathrm{gL}^{-1}$. Fe concentration is 146 also observed very high with an average concentration of $2.48 \pm 3.31 \mathrm{ppm}$. Fe exceeds BIS permissible limit $(0.3$ 147 ppm) at all the sites except two locations.

148 High concentration of $\mathrm{Mn}\left(133 \mu \mathrm{gL}^{-1}\right)$ and $\mathrm{Fe}\left(6.56 \mathrm{mgL}^{-1}\right)$ in the copper mine zone compared to quartzite and 149 granite mine zone is attributed to dissolution of sulphides. The average $\mathrm{U}$ concentration is observed lowest (13 $\left.\mu \mathrm{gL}^{-1}\right)$ in the copper mine zone. Baidya and Pal (2020) reported mineralization of uraninite near the Kolihan and

151 Chaandmari $\mathrm{Cu}$ deposits confirming the abundance of $\mathrm{U}$ in the copper mine zone. Uraninite is the probable source for $\mathrm{U}$ in the groundwater. The low concentration of $\mathrm{U}$ in groundwater of copper mine zone is attributed to the scavenging capacity of sulphides such as Mackinawite $\left(\mathrm{FeS}_{0.9}\right)$ or Fe-oxyhydroxides (Leermakers et al. 2016; Abdelouas et al. 1999). It also suggests immobilisation of $U$ in groundwater by sulphide dissolution. Thus, the present study confirms that sulphide mines have a buffering capacity to control the $\mathrm{U}$ mobilization in groundwater.

\section{Source of $U$}

The presence of U-rich granites and albetised quartzite rocks (GSI 2011) are a major source of $\mathrm{U}$ in groundwater of the North-Eastern part of Rajasthan. Statistical variation of $U$ concentration is classified into three classes (Fig. 2). The highest value of the first class is $30 \mu \mathrm{gL}^{-1}$ which is a WHO permissible limit and rest are further classified into two classes i.e. high (31-120 $\left.\mu \mathrm{gL}^{-1}\right)$ and severe (above $\left.120 \mu \mathrm{gL}^{-1}\right)$. In the copper mine zone, $\mathrm{U}\left(90 \mu \mathrm{gL}^{-1}\right)$ concentration is observed high at CE2 located near to the confluence of two geological groups (Ajabgarh and Alwar) compared to other locations. Fractures at the confluence of geological groups create oxic conditions which lead to the dissolution of minerals and permits U mobilization into groundwater (Abdelouas et al. 1999). Adithya et al. (2019) observed that groundwater in the oxidising conditions contain a higher concentration of dissolved U. Faults occur at the juncture of Ajabgarh and Alwar groups are attributed to the high mobility of $U$ in groundwater. The current study is preliminary in nature and further detailed study is needed with more number of samples from the confluence of geological groups. High contamination at ME3 $\left(80 \mu \mathrm{gL}^{-1} \mathrm{U}\right)$ is due to its closeness to albitite line. The albitite line is enriched in uraninite (Ray, 1990), a potential source of $U$ in the groundwater. ME3 is located in close proximity of Dabla granitoid and illegal mining is also observed in its surroundings. The high concentration of $\mathrm{U}$ in the groundwater is also attributed to anthropogenic activities (small scale mines).

MC and MS1 with a $\mathrm{U}$ concentration of 216 and $31 \mu \mathrm{gL}^{-1}$ are located close to active granite mines. Sedimentary rocks derived from granites are enriched in uranium concentration (Hobday and Galloway 1999). Almost all the locations in the quartzite mine zone are contaminated with U indicating its high mobility. Quartzite and granite mine zone are located in the vicinity of albitite line, where occurrence of $U$ mineralization is reported. Highest concentration of $\mathrm{U}$ i.e. $430 \mu \mathrm{gL}^{-1}$ is observed at QW3 close to Gothra granitoid. The high concentration of $\mathrm{U}$ is attributed to the presence of uranium enriched granite in the region (GSI 2011; Duggal et al. 2020). The variation in $\mathrm{U}$ concentration with respect to their geological settings indicates its geogenic origin in the groundwater.

178 Classifying the samples according to geological groups, the concentration of $\mathrm{Fe}$ and $\mathrm{Mn}$ is observed high at the 
fracture zones. The high concentration of elemental concentration is observed high in the fracture zone due to the presence of the oxic condition. Thus, fractures and faults at the confluence of two geological groups create oxic conditions which enhance the dissolution of Fe-rich minerals. The dissolved Fe and Mn minerals act as a scavenger for $U$ and thus, reducing the $U$ concentration which is supposed to be high at the confluence. At the Alwar group, Fe and Mn concentration are lowest among all the geological setups and $\mathrm{U}$ concentration is the highest. It indicates that in natural conditions sulphide mines acts as a buffer and control the dissolution of $U$ in groundwater. In the Khetri region, despite uranium-rich minerals, U concentration is observed low compared to its neighbouring locations, which is due to the buffering capacity of sulphide mines.

In the $\mathrm{KBC}$ region, the abundance of uraninite is observed in close vicinity to quartzite and copper mines (Ray 1990; Baidya and Pal 2020). However, a high concentration of $U$ is observed in the groundwater of the quartzite mine zone comparative to the copper mine zone. In the copper mine zone, a high concentration of $\mathrm{Fe}$ and $\mathrm{Mn}$ is observed and it is well known that the Fe is a scavenger for $\mathrm{U}$ in natural conditions. A strong correlation between $\mathrm{Fe}$ and $\mathrm{U}$ suggests that Fe scavenges $\mathrm{U}$ from the groundwater in the copper mine zone.

\section{Processes affecting $U$ concentration in groundwater}

High $U$ content in groundwater is due to weathering or anthropogenic dissolution of $U$ bearing minerals. The origin of $U$ in groundwater is geogenic but it is also significantly influenced by anthropogenic activities. Both geogenic and anthropogenic factors will be discussed in detail in the following sections.

\section{Weathering}

A shallow groundwater table with fractures and faults could be the reason for the leaching of $U$ in groundwater. The primary source in the region is $U$ bearing silicate minerals such as granite and uraninite. The region is known for $\mathrm{Cu}$ mineralization along with the occurrences of $\mathrm{Au} \pm \mathrm{Fe} \pm \mathrm{Co} \pm \mathrm{Ag} \pm \mathrm{REE} \pm \mathrm{U} \pm \mathrm{P}$ (Baidya et al. 2017). The geology of the region is very diverse and made up of different types of parent rocks. Fractures and faults are common features found at the boundary of two-parent rocks. Thus, a high concentration of $U$ in groundwater is attributed to mineral dissolution, faults or fractures in the region.

Groundwater depth is shallow and prone to leaching of elements because of precipitation. U concentration is observed high in shallow groundwater of semi-arid (Coyte et al. 2018) and arid region (Burow et al. 2017) due to leaching. The Khetri belt lies in the semi-arid region with shallow groundwater. The groundwater table is shallow hence weathering of $U$ bearing minerals is a significant contributor of $U$ in groundwater of the Khetri belt. In the Indian scenario, a high concentration of $U$ in groundwater is attributed to an oxidising condition which leads to the solubility of U by forming the soluble uranyl carbonates (Coyte et al. 2017; Brindha and Elango 2013).

\section{Anthropogenic activities}

Anthropogenic activities (industries or mining) leads to overexploitation or pollution of resources. Granite, quartzite and copper mines are major anthropogenic activities in the region. The concentration of $U$ is found high near quartzite and granite mines due to the abundance of granite minerals. $U$ does not show a significant correlation with Fe (except at the confluence of Ajabgarh and Alwar group) suggesting it is not associate with sulphide rich minerals and its origin is geogenic in the groundwater. At the confluence of Ajabgarh and Alwar group, fractures and faults promote the dissolution of sulphides and $U$ enriched silicates. $U$ and Fe have a 
217 significant correlation coefficient $\left(\mathrm{R}^{2}=0.97\right)$ at the confluence of Ajabgarh and Alwar group which indicates a

218 strong association between $\mathrm{U}$ and Fe. Additionally, fractures and faults create oxic conditions which are 219 responsible for the desorption of $U$ from clay minerals, metal oxides and oxyhydroxides (Zhou and Gu 2005;

220 Yang et al. 2014).

221 Neighbouring quartzite mines groundwater resources are overexploited and groundwater resources are completely 222 depleted at some locations. Overexploitation is a situation where the rate of groundwater extraction exceeds the 223 average rate of aquifer recharge (Foster and Loucks 2006). A high concentration of $U$ is attributed to 224 overexploitation of groundwater resources. The overexploitation of groundwater leads to an increase in the 225 concentration of major ions (Bagheri et al. 2019) and Fe (Gad et al. 2016). Quartzite mines lie in the Alwar group comprised of quartzite marble, schist and gneiss is a probable source in addition to Gothra granitoid.

\section{Future research scope}

228 In the present study, $\mathrm{U}$ concentration is observed less in copper mining zone compared to other locations despite the abundance of uraninite or granite, a source of U. It indicates that Fe-hydroxides or FeS are potential scavenger of $U$ from the groundwater. Mine waste enriched in iron sulphides is generated in huge amount across the globe (Thom et al. 2013; Eurostat, 2017). Thus, the present study purposes application of mining waste (tailings and overburden rocks) for the treatment of $U$ concentration from groundwater. The natural attenuation of $U$ from groundwater using mining waste needs further research, as mining waste is also a source of heavy metal contamination.

Mining waste is enriched in heavy metals (Punia et al. 2017), a source of groundwater contamination (Olías et al. 2021). Mining waste highly enriched in FeS generates acid mine drainage (AMD) and contaminates downstream groundwater. Identification of optimum concentration of mining waste for the removal of $U$ from groundwater is important. Achieving a balance between contamination and natural attenuation by mining waste is a topic of debate and needs further research. The dose of mining waste in groundwater after a regular interval of time would be beneficial as excessive FeS would generate AMD. A research is needed to identify the appropriate dose of mining waste and exposure duration to achieve the better removal of $U$ from the groundwater.

242 The Fe-(hydr)oxides and goethite have a capacity to remove $\mathrm{U}$ from groundwater via complexation process

243 (Logue et al. 2004; Gustafsson et al. 2009). Beneficiation of sulphide ore generates Fe enriched mining tailings 244 in abundant quantity and oxidation transforms sulphide minerals into stable goethite (Kim and Kim 2021). Iron oxyhydroxides and goethite controls U mobility in the environment (Lahrouch et al. 2021). Now a day's permeable reactor barrier (PRB) is widely used technology for the treatment of groundwater. Use of mine tailings in PRB could be a probable solution for the treatment of $U$ contamination. Further research is needed to facilitate the use mine waste as a reactive material for the manufacturing of PRB. The PRB coated with reactive material of Zero-valent iron nanoparticle are found feasible for removal and sequestration of $\mathrm{U}$ from groundwater ( $\mathrm{Li}$ et al. 2015). The injection of iron nanoparticles effectively removes $U$ contamination but the influence of other ions such as calcium, sulphate and carbonate on the water resources needs more studies (Jing et al. 2019).

The huge quantity of mining waste is burden for environment and its use for the treatment of groundwater would solve the problem of its disposal. The preparation of nano particles of Fe also increases the implementation cost at larger scale and the application of mining waste for the same would reduce the cost. Iron sulphide immobilizes 

identify the weight $\%$ concentration of mining waste which could be used for the removal of $U$ contamination from groundwater. As per our knowledge, no study has been carried for the removal of U contamination from groundwater using mining waste.

\section{Risk assessment}

Results show that at most of the locations HQ value lies near 1 and at four locations (QW3, CE2, MC, and ME3) it is above 1 indicating the probable adverse health impacts (Fig. 4). The reference dose value is taken as $4.53 \mathrm{mg}$ $\mathrm{kg}^{-1} \mathrm{day}^{-1}$ (AERB 2004). HQ varies from 0 to 7 with an average of 0.61 . Consumption of $\mathrm{U}$ contaminated water leads to nephrotoxicity, genotoxicity and developmental defects in humans (Brugge and Buchner 2011; Lariviere et al. 2007). Maximum HQ values $\sim 7$ demands further studies to assess the health impact of $U$ in the region.

\section{Conclusions}

266 The region is active in mining so the impact of anthropogenic activities can't be neglected. It is observed that sulphide mine acts as a buffer and prevents the dissolution of $U$-rich minerals in groundwater. $U$ concentration is found high in quartzite mine zone due to lack of buffers i.e. sulphides or Fe-hydroxides. The study recommends immobilization of $\mathrm{U}$ in groundwater using mining waste enriched in $\mathrm{Fe}$ sulphides and hydroxides. $\mathrm{U}$ concentration is observed high near to the confluence of two geological groups compared to other locations. Faults or fractures between two rocks cause oxic conditions and oxygen leads to the dissolution of Fe-rich minerals. Source of $\mathrm{U}$ in groundwater is uranium mineralization in granites, gneisses and quartzite rocks. The presence of fractures and faults significantly affects the uranium concentration in groundwater. Shallow aquifers with fractures and faults could be the reason for the mobility of $U$ in groundwater. The origin of $U$ in the groundwater is geogenic in nature but the influence of overexploitation of water can't be neglected. Overexploitation of groundwater increases the ionic concentration in groundwater. The health risk assessment for cancer indicates the HQ values $\sim 7$ demands further studies to assess the health impact of $\mathrm{U}$ in the region.

\section{Acknowledgments}

The postdoctoral fellowship of the Indian Institute of Technology Guwahati is acknowledged. The authors also acknowledge the support of IUAC for extending the ICPMS facility under the Geochronology project funded by the Ministry of Earth Sciences, Govt of India. The authors also acknowledge the help of Dr. Sumaya Prasad Dhal (Research Associate), IUAC in the handling of the instrument.

\section{References}

$: 1319-1329$

Abdelouas A, Lutze W, Nuttall HE (1999) Oxidative dissolution of uraninite precipitated on Navajo sandstone. J Cont Hyd 36:353-375 Groundwater Along the Lithological Contacts in Central Tamilnadu, India: An Isotope Hydrogeochemical 

Energy Regulatory Board.

292 Ayotte JD, Flanagan SM, Morrow WS (2007) Occurrence of Uranium and 222Radon in Glacial and Bedrock

293 Aquifers in the Northern United States, 1993- 2003. Citeseer.

294 Bagheri R, Nosrati A, Jafari H, Eggenkamp HGM, Mozafari M (2019) Overexploitation hazards and salinization

295 risks in crucial declining aquifers, chemo-isotopic approaches. J Hazard Mater 369:150-163.

296 Baidya AS, Pal DC (2020) Geochemical evolution and timing of uranium mineralization in the Khetri Copper

297 Belt, western India. Ore Geol Rev 127:103794

298 Baidya AS, Paul J, Pal DC, Upadhyay D (2017) Mode of occurrences and geochemistry of 952 amphibole in the 299 Kolihan-Chandmari copper deposits, Rajasthan, India: insight into the ore- 953 forming process. Ore Geol Rev $300 \quad 80: 1092-1110$

301 Banks D, Rohr-Torp E, Skarphagen H (1992) An integrated study of a Precambrian granite aquifer. riveter.

302 Southeastern Norway. Nor geol unders Bull 422:47-66

303 Blantz RC, Pelayo JC, Gushwa LC, Myers RR, Evan AP (1985) Functional basis for the glomerular alterations in 304 uranyl nitrate acute renal failure. Kidney Int 28:733-743

305 Brindha K, Elango L (2013) Occurrence of uranium in groundwater of a shallow granitic aquifer and its suitability 306 for domestic use in southern India. J Radioanal Nucl Chem 295:357-367 Brugge D, Buchner V (2011) Health effects of uranium: new research findings. Rev Environ Health 26:231-249 Burowa KR, Belitz K, Dubrovsky NM, Jurgens BC (2017) Large decadal-scale changes in uranium and bicarbonate in groundwater of the irrigated western U.S. Sc Total Environ 586:87-95

310 Cánovas CR, Macías F, Pérez-López R (2016) Metal and acidity fluxes controlled by precipitation/dissolution cycles of sulfate salts in an anthropogenic mine aquifer. J Contam Hydrol 188:29-43

312 Coyte RM, Jain RC, Srivastava SK, Sharma KC, Khalil A, Ma L, Vengosh, A (2018) Large-scale uranium contamination of groundwater resources in India. Environ Sci Technol Lett 5:341-347

314 Coyte RM, Singh A, Furst KE, Mitch WA, Vengosh A (2019) Co-occurrence of geogenic and anthropogenic contaminants in groundwater from Rajasthan, India. Sci Total Environ 688:1216-1227

316 Craft ES, Abu-Qare AW, Flaherty MM, Garofolo MC, Rincavage HL, Abou-Donia MB (2004) Depleted and natural uranium: chemistry and toxicological effects. J Toxicol Environ Health Part B 7:297-317

318 Cumberland SA, Douglas G, Grice K, Moreau JW (2016) Uranium mobility in organic matter-rich sediments: a review of geological and geochemical processes. Earth Sci Rev 159:160-185

320 Cuvier A, Panza F, Pourcelot L, Foissard B, Cagnat X, Prunier J, Beek P (2015) Uranium decay daughters from 321 isolated mines: accumulation and sources. J Environ Radioact 149:110-120

322 Das Gupta SP (1968) The structural history of the Khetri Copper Belt, Jhunjhunu and Sikar districts, Rajasthan. 323 Geol Sur India 98:170 

$\mathrm{n}<2$, associated with organic matter: a case study from Grants uranium region, New Mexico, USA. Chem Geol 251(1-4):33-49

Duggal V, Rani A, Balaram V (2016) Assessment of age-dependent radiation dose due to intake of uranium and thorium in drinking water from Sikar district, Rajasthan, India. Radiat Prot Dosim 171:257-261

Duggal V, Sharma S, Mehra R (2020) Risk assessment of radon in drinking water in Khetri Copper Belt of Rajasthan, India. Chemosphere 239:124782.

Foster S, Loucks D (2006) Non-renewable groundwater resources. UNESCO, IHP-VI, Series on Groundwater, No. 10, Paris, 81 pp.

Gad M, Dahab K, Ibrahim H (2016) Impact of iron concentration as a result of groundwater exploitation on the Nubian sandstone aquifer in El Kharga Oasis, western desert, Egypt. NRIAG J Astron geophys 5(1):216-237

Giblin AM, Batts BD, Swaine DJ (1981) Laboratory simulation studies of uranium mobility in natural waters. Geochim Cosmochim Acta 45:699-709

Gong Y, Tang J, Zhao D (2016) Application of iron sulfide particles for groundwater and soil remediation: A review. Water Research 89, 309-320

Gorman-Lewis D, Burns PC, Fein JB (2008a) Review of uranyl mineral solubility measurements. J Chem Thermodyn 40(3):335-352

343 Gorman-Lewis D, Fein JB, Burns PC, Szymanowski JE, Converse J (2008b) Solubility measurements of the 344 uranyl oxide hydrate phases metaschoepite, compreignacite, Na-compreignacite, becquerelite, and clarkeite. J Chem Thermodyn 40(6):980-990 properties of soddyite from solubility and calorimetry measurements. J Chem Thermodyn 39(4):568-575 Navrotsky A, Fein JB (2009) Thermodynamic properties of autunite, uranyl hydrogen phosphate, and uranyl orthophosphate from solubility and calorimetric measurements. Environ Sci Technol 43(19):7416-7422 GSI (2011) Geology and mineral resources of Rajasthan, Geological Survey of India, Miscellaneous Publication No. 30 Part 12, 3rd Revised Edition. ISSN 0579-4706, PGSI, 327, 700-2010 (DSK-II). emplacement mechanism of the granite massifs, Rajasthan. J Geol Soc India 52:417-432

355 Gustafsson JP, Dässman E, Bäckström M (2009) Towards a consistent geochemical model for prediction of uranium(VI) removal from groundwater by ferrihydrite. Applied Geochemistry 24, 454-462 
Hobday DK, Galloway WE (1999) Groundwater processes and sedimentary uranium deposits. Hydrogeol J $7(1): 127-138$

Hua B, Deng B (2008) Reductive Immobilization of Uranium(VI) by Amorphous Iron Sulfide. Environ. Sci. Technol. 42, 8703-8708

Hua B, Deng B (2008) Reductive immobilization of uranium(VI) by amorphous iron sulfide. Environ Sci Technol $42(23): 8703-8708$.

Jang JH, Dempsey BA, Burgos WD (2008) Reduction of U(VI) by Fe(II) in the presence of hydrous ferric oxide and hematite: effects of solid transformation, surface cover-age, and humic acid. Water Res 42 (8-9):2269-2277

Jing C., Li Y.L., Landsberger S. (2019) Review of soluble uranium removal by nanoscale zero valent iron. Journal of Environmental Radioactivity 164, 65-72

Jordens A, Cheng YP, Waters KE (2013) A review of the beneficiation of rare earth element bearing minerals. Miner Eng 41:97-114

Kanzari A, Gérard M, Boekhout F, Galoisy L, Calas G, Descostes M (2017) Impact of incipient weathering on uranium migration in granitic waste rock piles from former U mines (Limousin, France). J Geochem Explor $183: 114-126$

Katz SA (2014) The chemistry and toxicology of depleted uranium. Toxics 2:50-78

Kaur G, Mehta PK (2005) The Gothara plagiogranite: evidence for oceanic magmatism in a non-ophiolitic association, North Khetri copper belt, Rajasthan, India?. J Asian Earth Sci 25:805-819

Kaur P, Chaudhri N, Hofmann AW, Raczek I, Okrusch M, Skora S, Koepke J (2014) Metasomatism of ferroan granites in the northern Aravalli orogen, NW India: geochemical and isotopic constraints, and its metallogenic significance. Int J Earth Sci 103:1083-1112

Kaur P, Zeh A, Chaudhri N (2017) Palaeoproterozoic continental arc magmatism, and Neoproterozoic metamorphism in the Aravalli-Delhi orogenic belt, NW India: New constraints from in situ zircon U-Pb-Hf isotope systematics, monazite dating and whole-rock geochemistry. J Asian Earth Sc 136:68-88

Kim H-J, Kim Y (2021) Schwertmannite transformation to goethite and the related mobility of trace metals in acid mine drainage. Chemosphere, 269, 128720

Knight J, Lowe J, Joy S, Cameron J, Merrillees J, Nag S, Shah N, Dua G, Jhala K (2002) The Khetri Copper Belt, Rajasthan: iron oxide copper-gold terrane in the Proterozoic of NW India. In: Porter, T.M. (Ed.), Hydrothermal Iron Oxide Copper-Gold and Related Deposits: A Global Perspective, vol. 2. PGC Publishing, Adelaide, pp. 321341

Kozak K, Mazur J, Vautopic J, Grzadziel D, Kobal I, Omran KMH (2013) The potential health hazard due to elevated radioactivity in old uranium mines in Dolina Białego, Tatra mountains, Poland. Isot Environ Health Stud 49:274-282

Kurttio P, Komulainen H, Leino A, Salonen L, Auvinen A, Saha H (2005) Bone as a possible target of chemical toxicity of natural uranium in drinking water. Environ Health Perspect 113:68-72 
Lahrouch F, Guo N, Hunault MOJY, Solari PL, Descostes M, Gerard M (2021) Uranium retention on iron oxyhydroxides in post-mining environmental conditions. Chemosphere, 264(1), 128473

Lariviere D, Packer AP, Marro L, Li C, Chen J, Cornett RJ (2007) Age dependence of natural uranium and thorium concentrations in bone. Health Phys 92:119-126

Leermakers M, Phrommavanh V, Drozdzak J, Gao Y, Nos J, Descostes Ml (2016) DGT as a useful monitoring tool for radionuclides and trace metals in environments impacted by uranium mining: case study of the Sagnes wetland in France. Chemosphere 155:142-151

Li Z-J, Wang L, Yuan L-Y, Xiao C-L, Mei L, Zheng L-R, Zhang J, Yang J-H, Zhao Y-L, Zhu Z-T, Chai Z-F, Shi W-Q (2015) Efficient removal of uranium from aqueous solution by zero-valent iron nanoparticle and its graphene composite. Journal of Hazardous Materials 290, 26-33

Liesch T, Hinrichsen S, Goldscheider N (2015) Uranium in groundwater - Fertilizers versus geogenic sources. Sc Total Environ 536:981-995

Locock AJ, Burns PC (2003) Crystal structures and synthesis of the copper-dominant members of the autunite and meta-autunite groups: torbernite, zeunerite, metatorbernite and metazeunerite. Can Mineral 41:489-502

Logue, B.A., Smith, R.W., Westall, J.C., 2004. U(VI) adsorption on iron-coated sands: Comparison of approaches for modeling adsorption on heterogeneous environmental materials. Appl. Geochem. 19, 1937-1951.

Merkel BJ, Sperling B (1998) Hydrogeochemische Stoffsysteme Teil II. Bonn: Kommissionsvertrieb Wirtschaftsund Verlagsgesellschaft Gas und Wasser mbH.

Momčilović M, Kovačević J, Tanić M, Đorđević M, Bačić G, Dragović S (2013) Distribution of natural radionuclides in surface soils in the vicinity of abandoned uranium mines in Serbia. Environ Monit Assess 185(2)

Neiva AMR, Carvalho PCS, Antunes IMHR, Silva MMVG, Santos ACT, Cabral Pinto MMS, Cunha PP (2014) Contaminated water, stream sediments and soils close to the abandoned Pinhal do Souto uranium mine, central Portugal. J Geochem Explor 136:102-117

O'Brien TJ, Williams PA (1983) The aqueous chemistry of uranium minerals. 4. Schröckingerite, grimselite, and related alkali uranyl carbonates. Mineral Mag 47 (342):69-73

Olías M, Cánovas CR, Basallote MD (2021) Surface and Groundwater Quality Evolution in the Agrio and Guadiamar Rivers After the Aznalcóllar Mine Spill (SW Spain): Lessons Learned. Mine Water and the Environment 40, 235-249

Paradis CJ, Jagadamma S, Watson DB, McKay LD, Hazen TC, Park M, Istok JD (2016) In situ mobility of uranium in the presence of nitrate following sulfate-reducing conditions. J Contam Hydro 187:55-64

Patra A, Mohapatra S, Sahoo S, Lenka P, Dubey J, Tripathi R, Puranik V (2013) Age-dependent dose and health risk due to intake of uranium in drinking water from Jaduguda, India. Radiat Protect Dosim 155:210-216

Punia A, Siddaiah NS, Singh SK (2017) Source and assessment of heavy metal pollution at Khetri copper mine tailings and surrounding soil, Rajasthan, India. Bulletin of Environmental Contamination and Toxicology, 99, 633-641 
Rani A, Mehra R, Duggal V (2013) Analysis of uranium concentration in drinking water samples using ICPMS. Health Phys 104:251- 255

Ray AE, Bargar JR, Sivaswamy V, Dohnalkova AC, Fujita Y, Peyton BM, Magnuson TS (2011) Evidence for multiple modes of uranium immobilization by an anaerobic bacterium. Geochim Cosmochim Acta 75 (10):26842695

Roy Chowdhury M K and Das Gupta S P (1965) Ore-localization in the Khetri copper belt, Rajasthan, India. Econ Geol 60:69-88

Russell JJ, Kathren RL (2004) Uranium deposition and retention in a USTUR whole body case. Health Phys $86: 273-284$

Saini K, Singh P, Bajwa BS (2016) Comparative statistical analysis of carcinogenic and non-carcinogenic effects of uranium in groundwater samples from different regions of Punjab, India. Appl Radiat Isot 118:196-202 Sarkar SC, Dasgupta S (1980) Geologic setting, genesis and transformation of the sulfide deposits in the northern part of the Khetri copper belt, Rajasthan, India- an outline. Miner Deposita 15:117-137

442 Scherrer NC, Engi M, Gnos E, Jakob V, Lietchi A (2000) Monazite Analysis; From Sample Preparation to 443 Microprobe Age Dating and REE Quantification. 80. pp. 93-105

444 Selvi B, Vijayakumar B, Rana B, Ravi P (2016) Distribution of natural uranium in groundwater around 445 Kudankulam. Radiat Protect Environ 39:25-25

446 Sharma S, Kumar A, Mehra R, Mishra R (2017) Ingestion doses and hazard quotients due to intake of Uranium 447 in drinking water from Udhampur District of Jammu and Kashmir State, India. Radioprotection 52:109-118

448 Sharma T, Sharma A, Kaur I, Mahajan RK, Litoria PK, Sahoo SK, Bajwa BS (2019) Uranium distribution in 449 groundwater and assessment of age dependent radiation dose in Amritsar, Gurdaspur and Pathankot districts of 450 Punjab, India. Chemosphere 219:607-616

451 Shin W, Oh J, Choung S, Cho B, Lee K, Yun U, Woo N, Kim HK (2016) Distribution and potential health risk of 452 groundwater uranium in Korea. Chemosphere 163:108-115 Smith M, Roychoudhury AN (2013) Mobilisation of Iron from rocks in a fractured aquifer: Lithological and geochemical controls. Appl Geochem 31:171-186

Stalder E, Blanc A, Haldimann M, Dudler V (2012) Occurrence of uranium in Swiss drinking water. Chemosphere $86: 672-679$ Granitmassive des südöstlichen Bayerischen Waldes mit besonderer Berücksichtigung der geochemischen Uranexploration. RWTH Aachen. sequestration. Appl Geochem 35:244-254 
462 Tomiyama S, Igarashi T, Tabelin CB, Tangviroon P, Ii H (2019) Acid mine drainage sources and 463 hydrogeochemistry at the Yatani mine, Yamagata, Japan: A geochemical and isotopic study. J Contam Hydrol $464 \quad 225: 103502$

465 Tricca A, Porcelli D, Wasserburg GJ (2000) Factors controlling the groundwater transport of U, Th, Ra, and Rn. 466 J Earth Syst Sci 109:95-108

467 USEPA (1999) United States Environmental Protection Agency, Cancer risk coefficients for environmental 468 exposure to radionuclides. Federal Guidance Report No. 13, EPA 402-R-99-001.

469 Villa M, Manjon G, Hurtado S, Garcia-Tenorio R (2011) Uranium pollution in an estuary affected by pyrite acid 470 mine drainage and releases of naturally occur-ring radioactive materials. Mar Pollut Bull 62:1521-1529

471 Watson DB, Wu WM, Mehlhorn T, Tang GP, Earles J, Lowe K, Gihring TM, Zhang GX, Phillips J, Boyanov MI, 472 Spalding BP, Schadt C, Kemner KM, Criddle CS, Jardine PM, Brooks SC (2013) In situ bioremediation of 473 uranium with emulsified vegetable oil as the electron donor. Environ Sci Technol 47 (12):6440-6448

474 Wei Y, Jin L, Li Z, Liu J, Wang L, Pi X, Yin S, Wang C, Ren A (2019) Levels of uranium and thorium in maternal 475 scalp hair and risk of orofacial clefts in offspring. J Environ Radioact 204:125-131

476 WHO (2011) Guidelines for Drinking-water Quality. Fourth ed., vol. 1, World Health Organization, Geneva, 477 Switzerland.

478 Wu Y, Wang Y, Xie X (2014) Occurrence, behavior and distribution of high levels of uranium in shallow 479 groundwater at Datong basin, northern China. Sci Total Environ 472:809-817

480 Yang Q, Smitherman P, Hess CT, Culbertson CW, Marvinney RG, Smith AE, Zheng Y (2014) Uranium and 481 radon in private bedrock well water in Maine: geospatial analysis at two scales. Environ Sci Technol 48:42984824306

483 Zamora ML, Tracy BL, Zielinski JM, Meyerhof DP, Moss MA (1998) Chronic ingestion of uranium in drinking 484 water: a study of kidney bio effects in humans. Toxicol Sci 43:68-77

485 Zhou P, Gu BH (2005) Extraction of oxidized and reduced forms of uranium from contaminated soils: effects of 486 carbonate concentration and pH. Environ Sci Technol 39:4435-4440 
488 Figure 1 Study area C) Sampling locations superimposed on the geology (after Knight et al. 2002; Kaur et al. 2005).

490 Figure 2 Measured Uranium concentration in the Khetri Copper Belt.

491 Figure 3 Estimated concentration of heavy metals and U in different geological setups of Khetri region.

492 Figure 4 Locations with high Average Daily Dose (ADD) and Hazard Quotient (HQ) values. 

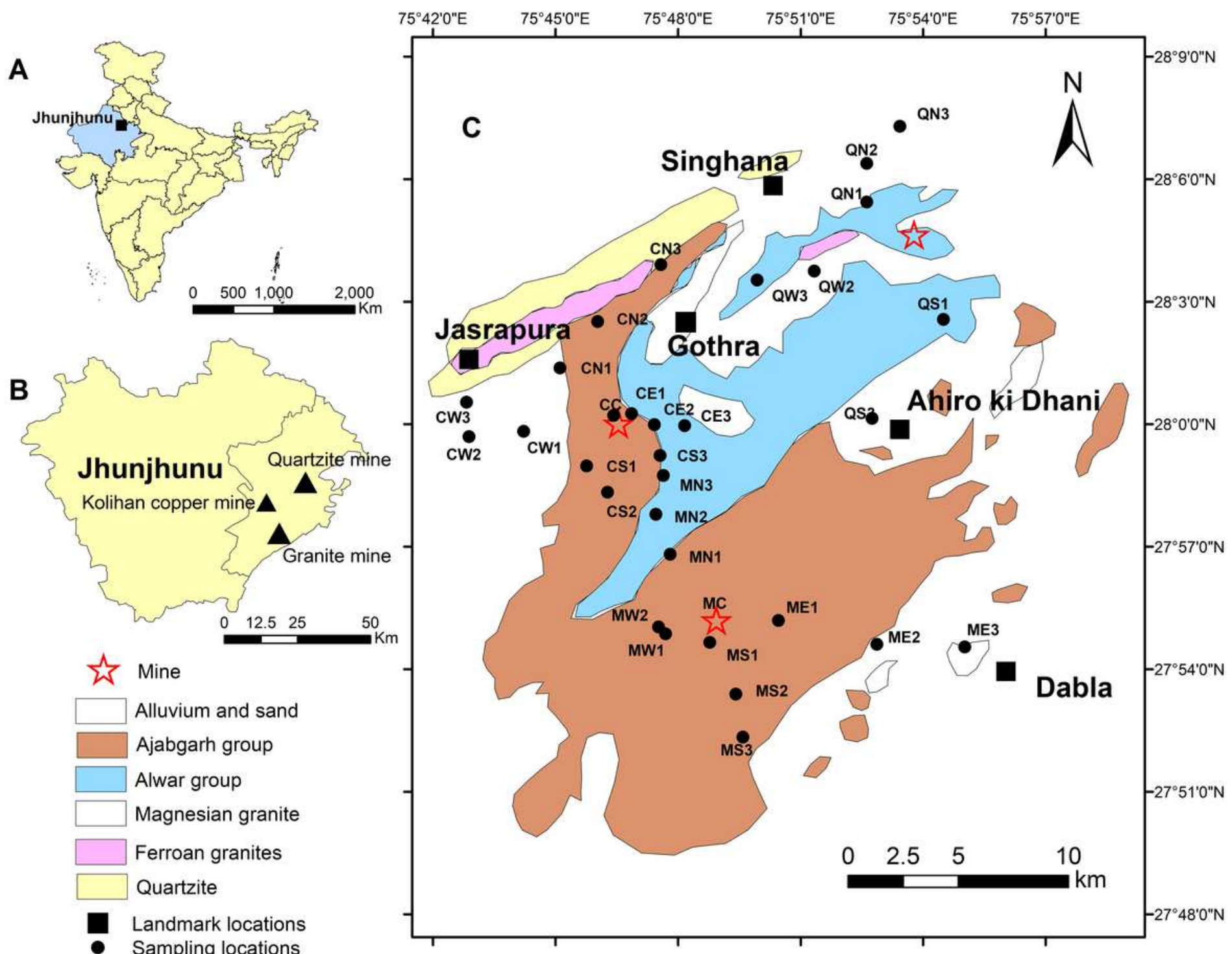

\section{Figure 1}

Study area C) Sampling locations superimposed on the geology (after Knight et al. 2002; Kaur et al. 2005). Note: The designations employed and the presentation of the material on this map do not imply the expression of any opinion whatsoever on the part of Research Square concerning the legal status of any country, territory, city or area or of its authorities, or concerning the delimitation of its frontiers or boundaries. This map has been provided by the authors. 


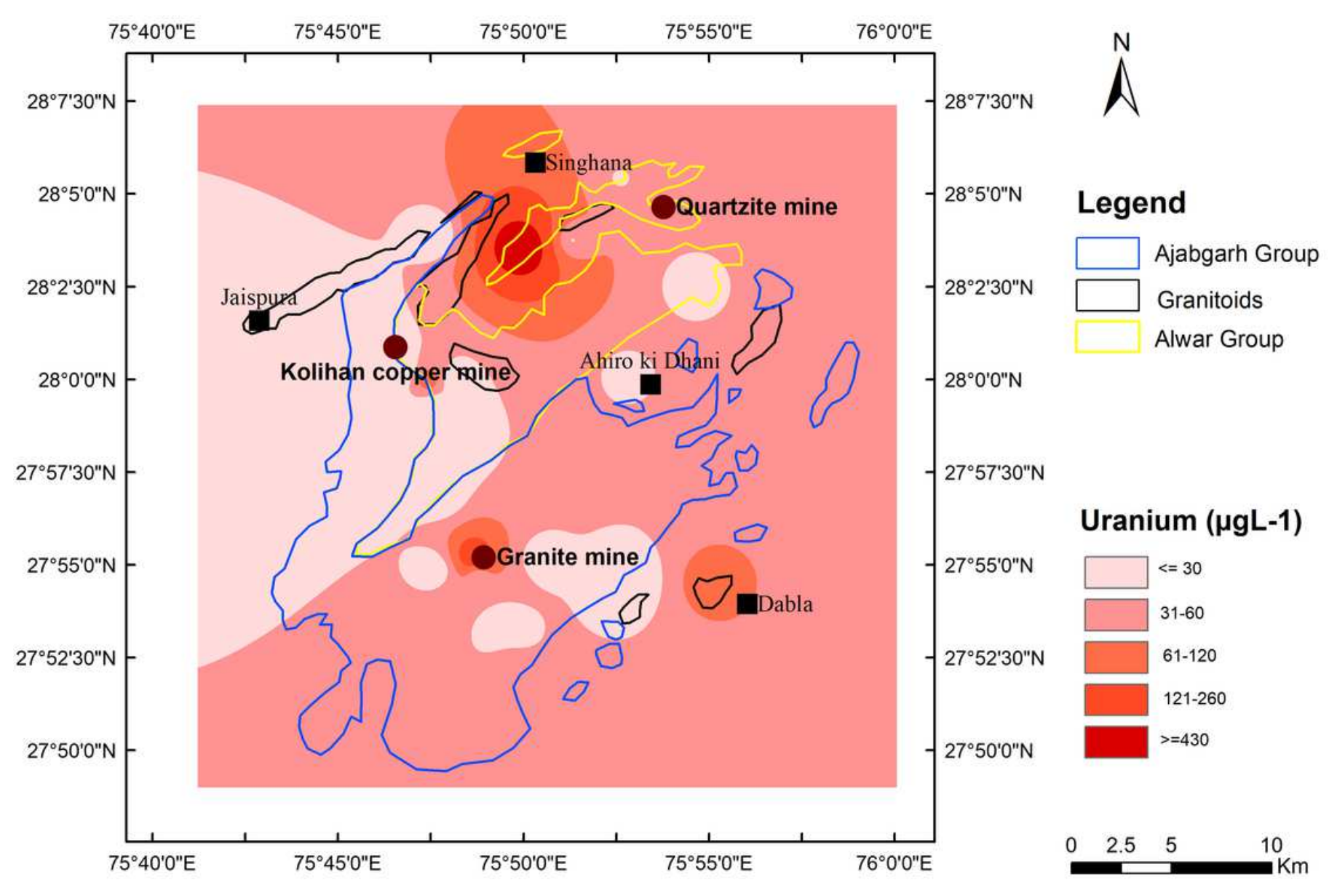

\section{Figure 2}

Measured Uranium concentration in the Khetri Copper Belt. Note: The designations employed and the presentation of the material on this map do not imply the expression of any opinion whatsoever on the part of Research Square concerning the legal status of any country, territory, city or area or of its authorities, or concerning the delimitation of its frontiers or boundaries. This map has been provided by the authors. 


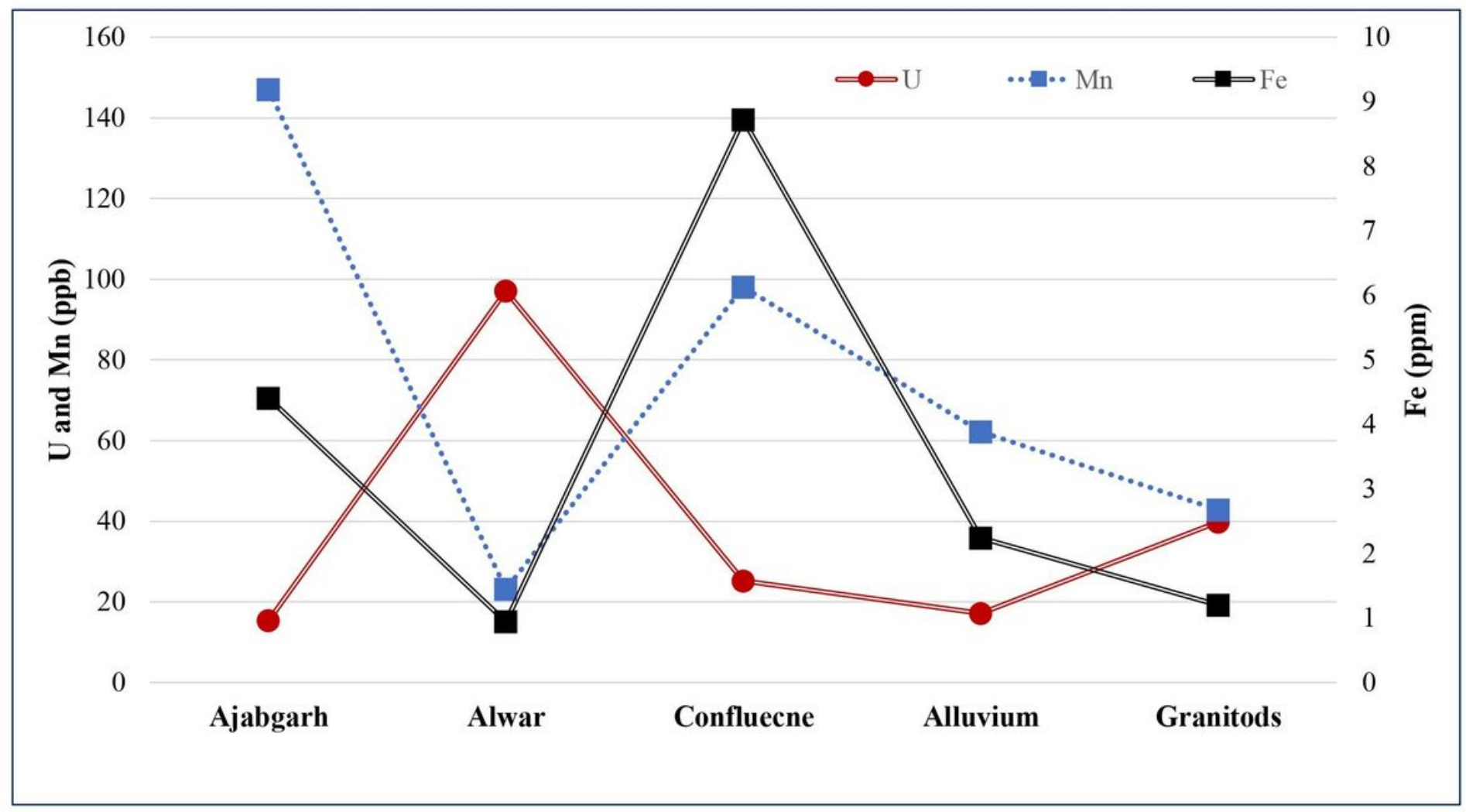

Figure 3

Estimated concentration of heavy metals and $U$ in different geological setups of Khetri region. 


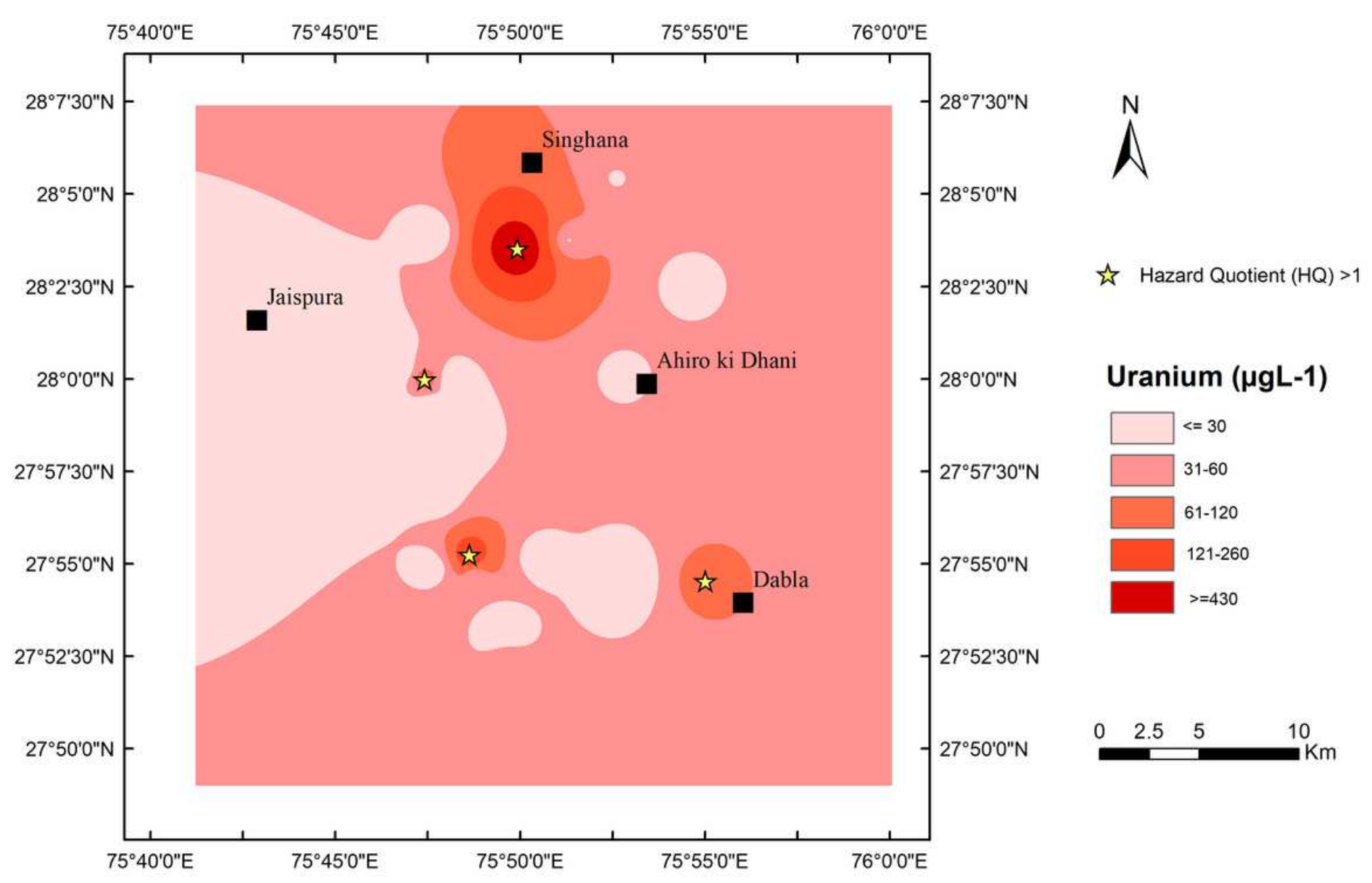

\section{Figure 4}

Locations with high Average Daily Dose (ADD) and Hazard Quotient (HQ) values. Note: The designations employed and the presentation of the material on this map do not imply the expression of any opinion whatsoever on the part of Research Square concerning the legal status of any country, territory, city or area or of its authorities, or concerning the delimitation of its frontiers or boundaries. This map has been provided by the authors. 